DOI 10.15517/rbt.v69i1.43515

\title{
Characterization and cytotoxic activity on glial cells of alkaloid-enriched extracts from pods of the plants Prosopis flexuosa and Prosopis nigra (Fabaceae)
}

\author{
Luciana Andrea Cholich ${ }^{1 *}$, María Elena Pistán ${ }^{1}$, Ana María Torres ${ }^{2}$, Hugo Héctor Ortega ${ }^{3}$,
} Dale R. Gardner ${ }^{4} \&$ Soledad Bustillo ${ }^{5}$

1. Clinical Department, Faculty of Veterinary Science, National University of the Northeast, Sargento Cabral 2139, Corrientes, Argentina; lucianaandreacholich@gmail.com,maelpi007@gmail.com

2. Natural Products Laboratory, IQUIBA-NEA CONICET, National University of the Northeast, Av. Libertad 5470, Corrientes, Argentina; amtorres39@yahoo.com.ar

3. Institute of Veterinary Sciences of Litoral (ICIVET), National University of Litoral (UNL), R.P. Kreder 2805, Esperanza, Santa Fe, Argentina; hhortega@hotmail.com

4. USDA-ARS Poisonous Plant Research Laboratory, 1150 E 1400 N, Logan, Utah 84341, USA; dale.gardner@usda.gov

5. Biological and Molecular Investigations Group (GIBYM), IQUIBA-NEA CONICET, National University of the Northeast, Av. Libertad 5470, Corrientes, Argentina; solebustillo@yahoo.es

* Correspondence

Received 18-VIII-2020. Corrected 12-XI-2020. Accepted 18-XI-2020.

\begin{abstract}
Introduction: Prosopis spp. pods have shown to be a potential source of protein and energy in livestock. However, prolonged ingestion of some of these species produces neurological symptoms in ruminants. Objective: In the present study, the alkaloid content and the in vitro neurotoxic activity of alkaloid enrichedextracts from $P$. flexuosa and $P$. nigra pods were determined in order to elucidate the mechanism of animal poisoning caused by these species. Methods: The main alkaloids present in both extracts were analysed by high performance liquid chromatography-high resolution mass spectrometry (HPLC-HRMS). The cytotoxic activity of Prosopis alkaloid enriched-extracts in primary mixed glial cell culture was assessed by phase contrast microscopy and using neutral red, and lactate dehydrogenase (LDH) activity assays. Results: Juliprosine and juliprosopine were identified in P. flexuosa pods, while the absence of these alkaloids in P. nigra was confirmed. Both extracts $(5-30 \mu \mathrm{g} / \mathrm{mL})$ induced in a dose dependent manner, morphological alterations, such as swelling, enlargement and detachment from the culture surface. Consistent with this, decrease in cell viability and release of LDH 48 hours after exposure, revealed that $P$. flexuosa pods was significantly more cytotoxic than $P$. nigra. Conclusions: In $P$. flexuosa pods, juliprosine and juliprosopine alkaloids were identified for the first time. Moreover, the present study suggests that the cytotoxic effect displayed by both extracts is due to its alkaloid content. However, the presence of piperidine alkaloids in P. flexuosa could explain the greater cytotoxicity on glial cells with respect to P. nigra that was not shown to contain these alkaloids.
\end{abstract}

Key words: algarrobos; cytotoxicity; piperidine alkaloids; Prosopis species.

Cholich, L.A., Pistán, M.E., Torres, A.M., Ortega, H.H., Gardner, D.R., \& Bustillo, S. (2021). Characterization and cytotoxic activity on glial cells of alkaloid-enriched extracts from pods of the plants Prosopis flexuosa and Prosopis nigra (Fabaceae). Revista de Biología Tropical, 69(1), 197-206. DOI 10.15517/rbt.v69i1.43515 
Genus Prosopis belongs to the Fabaceae family, subfamily Mimosoideae, and is an important tree in arid, semi-arid, tropical and subtropical regions of the world. Most species are found in the Chaco biogeographical region of South America (Schmeda-Hirschmann, Theoduloz, Jiménez-Aspee, \& Echeverría, 2020). Specifically, in Argentina, P. nigra and $P$. flexuosa are geographically distributed along with P. alba, P. hassleri and P. chilenssis, throughout different ecoregions, including Chaco, Espinal Norte and Pampeana, which are locally known as "Algarrobos" (Palacios \& Brizuela, 2005).

The pods of this genus are a feed source for animals in many regions of the world, due to their nutritional value (Silva, 1981; RietCorrea et al., 2012). Recently an outbreak of nervous disease has been reported in cattle associated with consumption of Prosopis sp. pods for which clinical signs include tongue protrusion, twitches and tremors of muscles of mastication, weight loss and lethargy (Micheloud, Caro, Cholich, Martinez, \& Gimeno, 2019). These clinical signs are similar to those reported in intoxicated animals by $P$. juliflora from Brazil (Lima, Riet-Correa, Amorin, \& Sucupira, 2004; Tabosa, Riet-Correa, Simoes, Medeiros, \& Nobre, 2004; Silva, Riet-Correa, Medeiros, \& Oliveira, 2006; Tabosa et al., 2006; Assis, Medeiros, Araujo, Dantas, \& RietCorrea, 2009; Câmara et al., 2009).

Prosopis species are reported to produce a number of different alkaloids including simple phenolic amines such as phenethylamine, tyramine and tryptamine from fruit of $P$. nigra and aerial parts of P. flexuosa (Moro, Graziano, \& Coussio, 1975; Tapia et al., 2000; Pérez et al., 2014). Besides, more complex molecules such as the piperidine alkaloids: $2-\beta$-methyl-3$\beta$-hydroxy-6- $\beta$-piperidinedodecanol, juliprosopine and juliprosine were isolated from leaves of P. flexuosa (Tapia et al., 2000). Juliprosopine, juliprosine and juliprosinene have been identified as the main toxins from $P$. juliflora pods and leaves of Brazil (Ahmad, Sultana, \& Qazi, 1989; da Silva, da Silva, Silva, \& Costa, 2018; Tabosa et al., 2000).
Although, the usage of Prosopis pods are among the oldest foods used by the Amerindian for animal feeding, specifically in the North and center of Chile, Northwestern Argentina and Southern Peru, little is known about the composition of these Algarrobo pods (Schmeda-Hirschmann et al., 2020). In vitro studies have shown that alkaloidal extract or alkaloid fraction of the pods and leaves of $P$. juliflora have a direct action in central nervous system (Hughes et al., 2005; Silva et al., 2007; Silva et al., 2013; Silva et al., 2017). However, toxicological analyses of pods of species from $P$. flexuosa and $P$. nigra, along with in vitro cytotoxic activity of plant extracts have yet to be reported.

The aim of this study was to characterize the alkaloid content and in vitro neurotoxic activity of alkaloid enriched extracts from Prosospis flexuosa and Prosopis nigra pods in order to elucidate the mechanism of animal poisoning caused by Prosopis sp.

\section{MATERIALS AND METHODS}

Plant Material: P. flexuosa subsp. flexuosa pods were collected from Salta, Northwest of Argentina, while P. nigra subsp. nigra pods were collected from Chaco, Northeastern of Argentina. Voucher herbarium specimens (CTES-1193, P. flexuosa and CTES-993, $P$. nigra) were identified by Lic. Walter Medina and deposited at the "Instituto de Botánica" from Facultad de Ciencias Agrarias (UNNECONICET) in Corrientes, Argentina. The pods were dried at $37{ }^{\circ} \mathrm{C}$ to a constant weight and then pulverized in a mill.

Preparation of alkaloid-enriched extracts from $P$. flexuosa and $P$. nigra: Alkaloid-enriched extracts were obtained from $500 \mathrm{~g}$ of $P$. flexuosa and P. nigra pulverized pods by an acid/basic extraction, as previously described by Ott-Longoni, Viswanathan, \& Hesse (1980). Briefly, dry pods samples were firstly defatted with hexane $(1 \mathrm{~L})$ for 10 days and then extracted with methanol (1 L) for 7 days. The solution was filtered, and the 
methanol extract concentrated under low pressure at $40{ }^{\circ} \mathrm{C}$, stirred with $0.2 \mathrm{~N} \mathrm{HCl}$ and once more filtered. The acid extract was washed with chloroform and basified with ammonium hydroxide, and then was extracted with chloroform. Subsequently, the chloroform solution was evaporated to dryness and referred as the "alkaloid-enriched extract" (AEE).

The quantitative determination of total alkaloid content in AEEs of $P$. flexuosa and $P$. nigra pods was performed with the bromocresol green method described by Biju, Sulaiman, Satheesh, \& Reddy (2014). Total alkaloids were calculated as $\mathrm{mg}$ of atropine equivalents (mg AE) per $g$ of extract.

HPLC Analyses: HPLC-HRMS analyses were performed similar to that previously described dos Santos et al. (2013). The analytical samples were injected onto a Synergi Hydro column $(75 \times 2 \mathrm{~mm}, 4 \mu)$. Eluting solvents were acetonitrile (mobile phase A) and $0.05 \%$ TFA $/ 0.5 \%$ acetic acid (mobile phase B) using a flow rate of $0.4 \mathrm{~mL} / \mathrm{min}$. A linear gradient started at $5 \%$ (B) from 0-2 min, increasing to $70 \%$ (B) from $2-15 \mathrm{~min}$, returning to $5 \%$ (B) at $18 \mathrm{~min}$. The mobile phase was delivered and samples injected using an Ultimate 3000 HPLC (Thermo Scientific, San Jose, CA, USA) and the column eluent was connected directly to the heated electrospray source of an Q-Exactive high resolution mass spectrometer (Thermo Scientific, San Jose, CA, USA), operated in the positive ion mode, and calibrated per the manufacturer's instructions with a scan range 100-1 $000 \mathrm{Da}$, resolution 70 000, microscans 1 , sheath gas flow 35 , auxiliary gas flow 10 , spray voltage $4 \mathrm{kV}$, capillary temperature $320^{\circ} \mathrm{C}$, S lens RF field 55 , and auxiliary gas temperature $300{ }^{\circ} \mathrm{C}$. Identification of the alkaloids juliprosine and juliprosopine were based on comparison of mass spectra with that previously rerported (dos Santos et al., 2013) and with HRMS data. Juliprosine: M+ $=626.5628$ observed (626.5619 required for C40H72N3O2; $\Delta 0.86$ ppm). Juliprosopine: $\mathrm{MH}+=630.5929$ observed (630.5932 required; $\Delta 0.34 \mathrm{ppm})$.
Primary Mixed Glial Cell Culture and treatments: Primary glial cell cultures were prepared from 1-3 days old mice (CF-1). Animal protocols were in accordance with the ethical principles of animal experimentation and approved by protocol $N^{\circ} 0069 / 2016$ of the Ethics and Biosafety Committee of UNNE. Briefly, forebrains free of meninges $(\mathrm{N}=5)$ were removed aseptically and mechanically dissociated by repeated pipetting. Dissociated cells were plated onto poly-D-lysine-coated $25 \mathrm{~cm}^{2}$ flasks or 24-well plates for experiments using a micro-full medium: Dulbecco's minimum essential medium (DMEM-F12) supplemented with fetal bovine serum (FBS $10 \%$ ), (Natocor), non-essential amino acids (MEM NEAA 100 X-1 \%), L-Glutamine (1 $\%)$, Gentamicin $(10 \mu \mathrm{g} / \mathrm{mL})$ and PenicillinStreptomycin (1\%). Cells were incubated at 37 ${ }^{\circ} \mathrm{C}$ and $5 \% \mathrm{CO}_{2}$, medium was replaced every 5 days and confluency was achieved after $18 \pm$ 3 days in vitro (DIV). Unless stated otherwise, reagents were purchased from Gibco (Buenos Aires, Argentina), or Sigma-Aldrich (St. Louis, MO, USA).

Culture purity of mixed glial isolation was determined by immunocytochemistry using specific markers for microglia (Iba-1) and astrocytes (GFAP).

After $18 \pm 3$ days in vitro, glial cells were harvested from subconfluently monolayers after exposure to $0.25 \%$ trypsin/EDTA (1 $\mathrm{X})$ (Gibco) at $37{ }^{\circ} \mathrm{C}$. The resuspended cells were seeded in 96-well microplates at an approximate initial density of $40 \times 103$ cells per well, in growth medium (DMEM-F12, $10 \%$ FBS). When monolayers reached confluence, the media was changed to include AEE from P. flexuosa or P. nigra, which were previously dissolved in $0.1 \%$ dimethylsulfoxide (DMSO, Sigma, St. Louis, MO), at different concentrations ( 5 to $30 \mu \mathrm{g} / \mathrm{ml}$ ) in medium supplemented with $10 \%$ of FBS, and were added to cells in a total volume of $200 \mu \mathrm{L} /$ well. Plates were further incubated for $48 \mathrm{~h}$ at $37{ }^{\circ} \mathrm{C}$ and $5 \% \mathrm{CO}_{2}$. Control cells were treated with DMSO diluted in culture medium at the higher equivalent volume used in the treated groups. 
Morphological analysis: After $48 \mathrm{~h}$ incubation, cells were observed by phase contrast microscopy (Axiovert 40®, Carl Zeiss Argentina) to evaluate morphological changes induced by AEEs. The images were taken with a digital camera (Canon CCD $2272 \times 1704$, Argentina) before and after treatments.

Neutral red assay: Cell viability was quantified after $48 \mathrm{~h}$ by neutral red (NR) incorporation, as described Repetto, del Peso, \& Zurita (2008), with slight modifications. Briefly, culture medium was removed and 200 $\mu \mathrm{L}$ of DMEM without FBS and containing 4 $\mathrm{mg} / \mathrm{mL}$ of NR (Sigma Aldrich) in 1:100 dilution was added to each well. After $2 \mathrm{~h}$ of incubation, medium was removed and cells were washed with buffered saline solution (PBS). Subsequently, $200 \mu \mathrm{L}$ of $1 \%$ acetic acid in 50 $\%$ ethanol were added for dye solubilization and gently shaken for 10 minutes for full dissolution. The absorbance was measured at 540 $\mathrm{nm}$ with a microplate spectrophotometer. The percentage of cell viability was determined by comparison with the mean absorbance of control wells (without AEEs), considered as $100 \%$.

Cytolysis assay: An additional assay was performed to assess cytolysis determining the release of the cytosolic enzyme lactic dehydrogenase (LDH), as previously described by Lomonte, Tarkowski, \& Hanson (1994). Aliquots of the supernatant in culture wells were collected, and LDH activity was determined by using a commercial kit (Wiener, LDH-P UV). Enzymatic activity was expressed as LDH (IU/L) activity relative to that of non-treated cells. All assays were carried out in triplicates.

Statistical analysis: The values obtained were expressed as the mean \pm standard deviation (SD). Data represents results from at least three separate experiments, each performed in triplicate. Differences among means were tested for statistical significance using a double-way ANOVA followed by Tukey's test. Statistical analysis was performed using
Infostat software. The level of significance was set at $\mathrm{P} \leq 0.05$.

\section{RESULTS}

Analysis of alkaloids in P. flexuosa and $P$. nigra enriched extracts: The total alkaloid content in AEEs of $P$. flexuosa and $P$. nigra were expressed in milligrams atropine equivalent (mg AE). The results showed values of $200.3 \mathrm{mg} \mathrm{AE} / \mathrm{g} \mathrm{AEE}$ and $34.5 \mathrm{mg}$ $\mathrm{AE} / \mathrm{AEE}$ respectively.

In order to determine the main alkaloids from Prosopis species pods, samples of AEEs were analysed by HPLC-HRMS. In Fig. 1, the extract of $P$. flexuosa pods revealed juliprosine $m / z=626[\mathrm{M}]^{+}$to be the major alkaloid detected. Juliprosopine, $m / z=630[\mathrm{M}+\mathrm{H}]^{+}$, was also detected in a relative concentration of approximately $15 \%$ compared to juliprosine. Regarding the extract of $P$. nigra pods, no juliprosine $(\mathrm{Rt}=9.34 \mathrm{~min})$ or juliprosopine $(\mathrm{Rt}=9.74)$ alkaloids were detected from the HPLC-MS chromatogram (Fig. 2) or indicated by ions at $m / z 626$ or 630 (Fig. 3), confirming the absence of these alkaloids in the extract of P. nigra. No evidence of the previously reported alkaloids for P. nigra ( $\beta$ - phenethylamine, eleagine, harman, tryptamine, N-acetyltryptamine and tyramine) (Moro et al., 1975) were observed from the HPLC-MS data and the alkaloids found in low concentration by the bromocresol green method could not be identified.

Cytotoxicity of $P$. flexuosa and $P$. nigra alkaloid enriched extracts on mixed glial cells: Mixed glial cultures were morphologically identified and a predominance of microglia and astrocytes was demonstrated (Fig. 4A). When $P$. flexuosa and $P$. nigra AEEs were incubated at different concentrations with glial cells, morphological alterations included swelling, enlargement, and often detachment from the well surface were observed. Severely damaged cells, with membrane rupture and cell debris released into the medium were detected. These morphological alterations were more evident at the highest doses tested and for those 


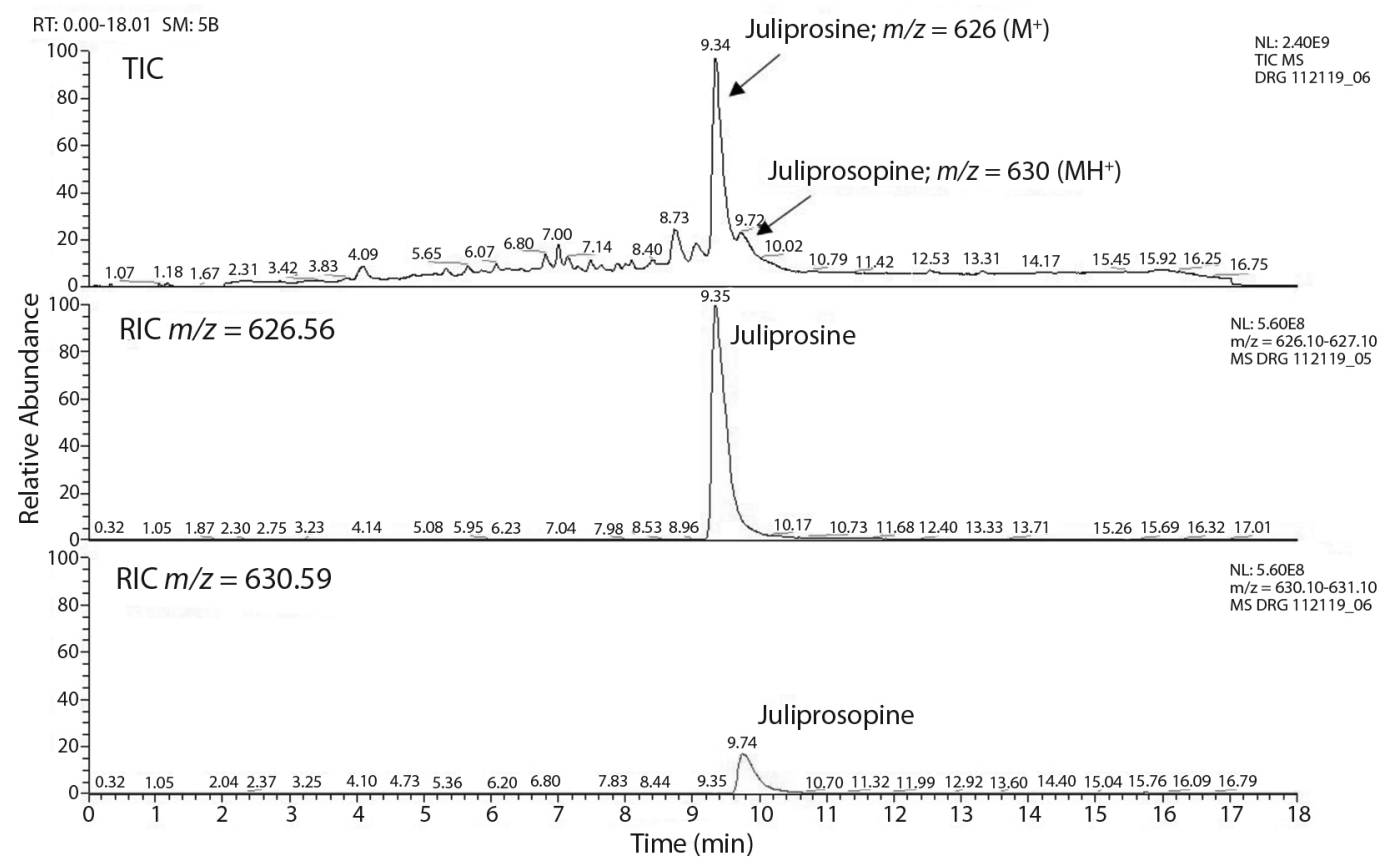

Fig. 1. HPLC-HRMS chromatogram obtained for alkaloid enriched-extract of $P$. flexuosa pods.

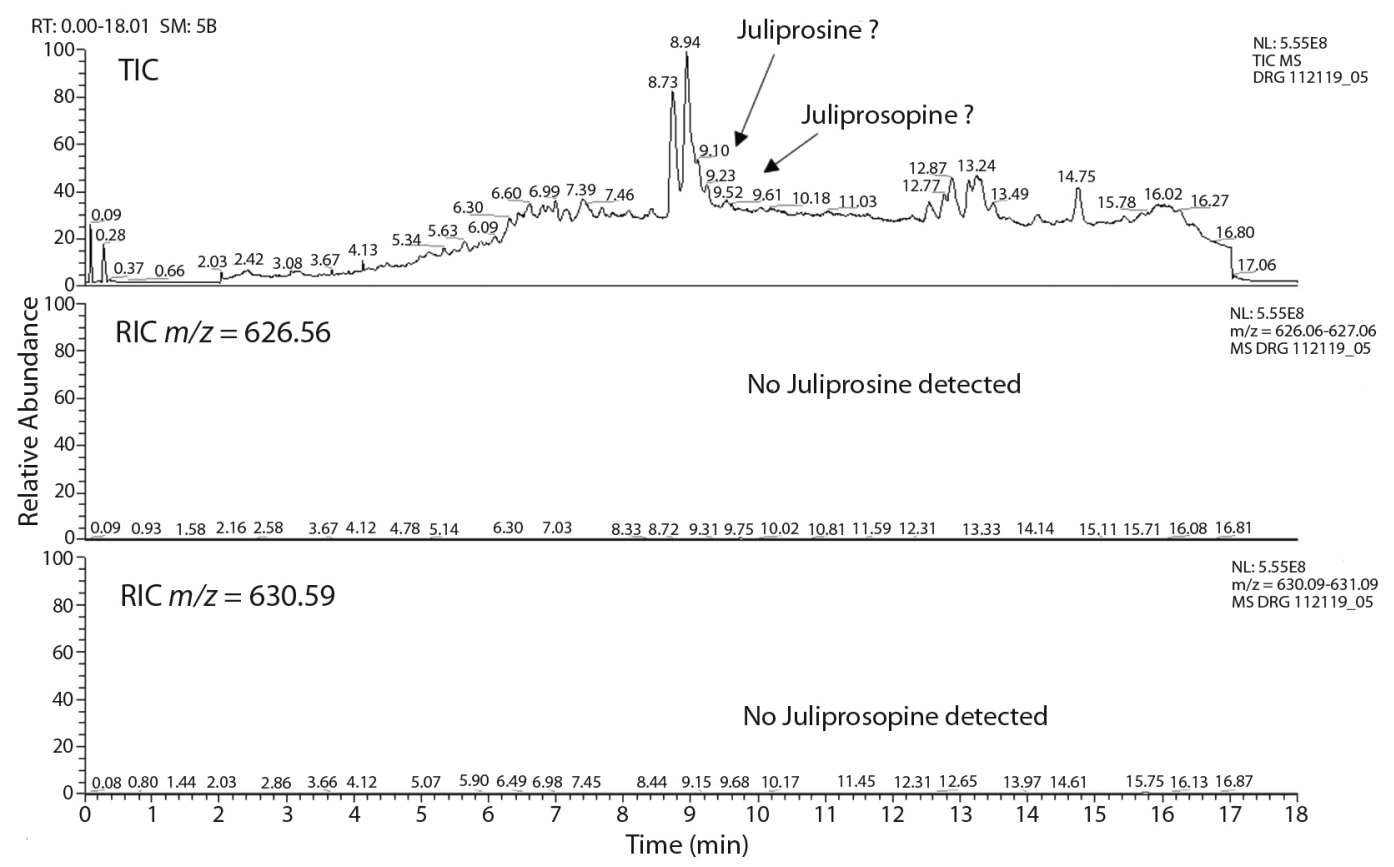

Fig. 2. HPLC-HRMS chromatogram obtained for alkaloid enriched-extract of $P$. nigra pods. 


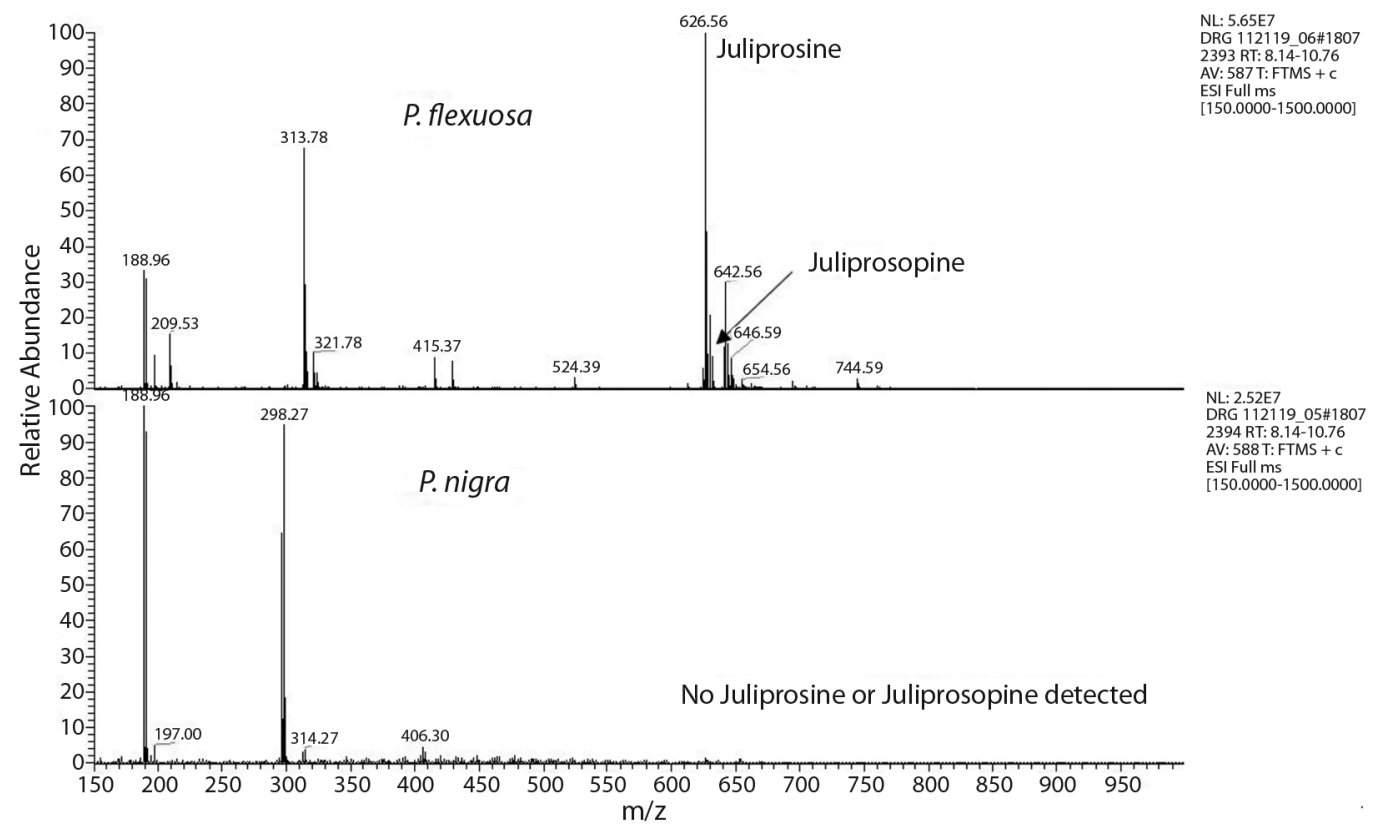

Fig. 3. Mass spectra of the region (Retention time $8-10.5 \mathrm{~min}$ ) for the alkaloid enriched-extracts of P. flexuosa and P. nigra pods.
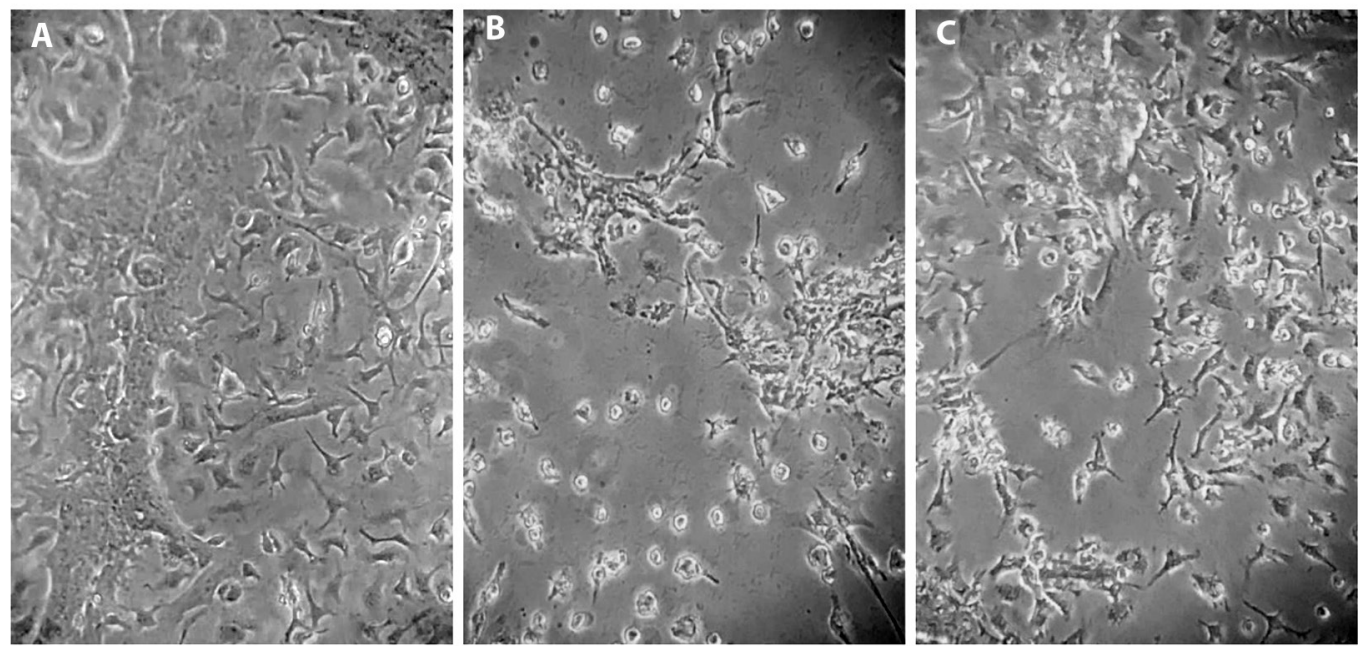

Fig. 4. Morphological analysis of primary mixed glial cells under phase contrast microscopy after $48 \mathrm{~h}$ of incubation with alkaloid enriched extracts. A. Control (x 200 magnification). B. P. flexuosa (30 $\mu \mathrm{g} / \mathrm{mL}$ - x200). C. P. nigra $(30 \mu \mathrm{g} / \mathrm{mL}-\mathrm{x}$ 200 magnification). 


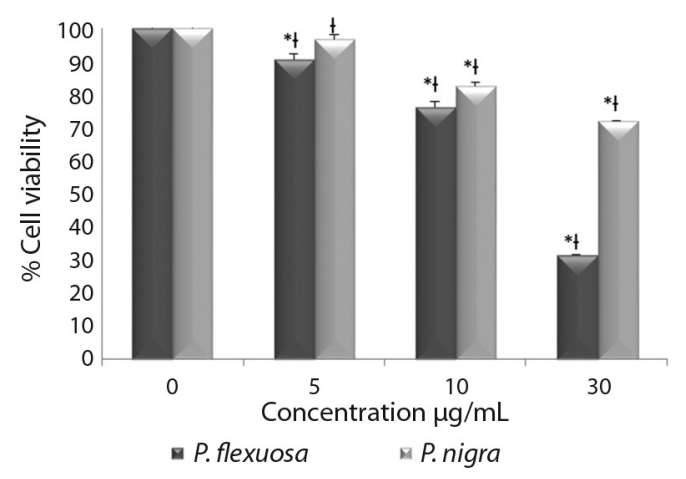

Fig. 5. Cell viability determined by neutral red uptake assay. Each column represents mean \pm SD of triplicates, in three independent experiments, $* \mathrm{P}<0.01$ differences compared to the control and ${ }^{1} \mathrm{P}<0.01 P$. flexuosa vs $P$. nigra.

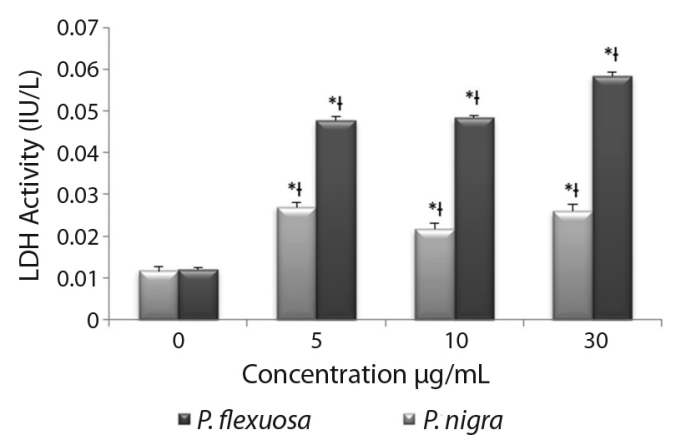

Fig. 6. LDH activity (UI/L). Each column represents mean \pm SD of triplicates, in three independent experiments, ${ }^{*} \mathrm{P}<$ 0.01 differences compared to the control and ${ }^{1} \mathrm{P}<0.01 P$. flexuosa vs $P$. nigra.

cultures incubated with AEE from P. flexuosa (Fig. 4B, Fig. 4C).

Coincident with the observed morphological changes, neutral red assay demonstrated that both extracts induced a dose-dependent cytotoxicity, being AEE from P. flexuosa significantly $(\mathrm{P}<0.01)$ more toxic than control and AEE from $P$. nigra. The difference in decreased cell viability was again more evident at the highest dose tested $(30 \mu \mathrm{g} / \mathrm{mL})$, being approximately $70 \%$ for $P$. flexuosa and 30 $\%$ for P. nigra (Fig. 5). The release of lactate dehydrogenase confirmed the aforementioned cytotoxic effects and the differences between extracts, also indicating an alteration of the cell membranes after $48 \mathrm{~h}$ of incubation (Fig. 6).

\section{DISCUSSION}

Prosopis sp. represents an important forest resource. However, some species can become a weed in native vegetation areas and induce spontaneous poisoning in animals, especially when it is used as the sole source of alimentation and during extreme drought conditions (Riet-Correa et al., 2012; Kumar \& Mathur, 2014; Ruiz-Nieto et al., 2020). Tabosa et al. (2006), reports neurotoxic damage to the central nervous system (CNS) in cattles fed during 6 months with a ration containing 50-75\% of P. juliflora pods from Brasil after. Similarly, in Argentina, Micheloud et al. (2019) have described animal poisoning with nervous clinical signs. However, it could not be specifically confirmed that the intoxication was due to the Prosopis species.

On the other hand, several in vitro studies demonstrate that some Prosopis species such as . flexuosa, P. nigra, P. juliflora, P. cineraria and $P$. strombulifera, exert antioxidant, anti-inflammatory, antimicrobial, anticancer, antidiabetic effects and enzyme inhibition associated with metabolic syndrome (Hapon et al., 2014; Henciya et al., 2017; Pérez et al., 2014; Soni et al., 2018; Tapia et al., 2000). Nevertheless, no documented results are available about the in vitro toxicological effects of the pods of P. flexuosa and P. nigra.

The identification of toxic principles in pods from Prosopis species is necessary to limit the amount of this feed resource in livestock nutrition, for the prevention of animal poisoning. Thereafter, in this study we have identified the main alkaloids present and the cytotoxicity on glial cells of alkaloid extracts from pods of two species of Prosopis, widely distributed in Argentina and in other countries of South America (Palacios \& Brizuela, 2005). Juliprosine and juliprosopine alkaloids, had been reported as present in P. flexuosa leaves (Tapia et al., 2000). The analysis conducted here by HPLC-HRMS confirmed the occurrence of these alkaloids in the pods of this plant as well. According to dos Santos et al. (2013), juliprosine and juliprosopine were the most 
abundant chemical compounds present in the pods of $P$. juliflora. Conversely, juliprosine and juliprospine were not found in $\mathrm{t}$ in the AEE of $P$. nigra pods. Through these results, we would rule out $P$. nigra as the cause of the spontaneous poisoning in animals.

Cytotoxic results here obtained, demonstrate that AEEs from pods of $P$. flexuosa and $P$. nigra induce a dose-dependent effect in primary mixed glial culture. Morphological changes were compatible with the necrosis cell death mechanism and included enlarged cells, detachment and disruption of plasma membrane. This cell membrane rupture resulted in the release of cytoplasmic lactate dehydrogenase (LDH) and confirmed the cytolysis triggered by these AEEs. Decrease of cell viability, cell morphological alterations and the evidence of cytolysis after incubation with AEEs, indicated that $P$. flexuosa was more cytotoxic than $P$. nigra at all doses tested. This difference could be attributable to the presence of piperidine alkaloids in $P$. flexuosa and the low alkaloid content detected in P. nigra. In addition, pods of P. flexuosa induced a cytotoxic effect similar to P. juliflora from Brazil, which comparably releases LDH when cells cultures were exposed at equivalent extract concentrations (Hughes et al., 2005; Silva et al., 2007).

In conclusion, we have described, for the first time, the presence of juliprosine and juliprosopine alkaloids in P. flexuosa pods. On the other hand, the present study suggest that the cytotoxic effect displayed by both AEEs from P. flexuosa and P. nigra pods are due to its alkaloid content. Furthermore, the presence of these piperidine alkaloids in $P$. flexuosa pods could explain the greater cytotoxicity on glial cells with respect to $P$. nigra that was not shown to contain these alkaloids. Further studies are needed to elucidate the molecular mechanism for these triggered toxic effects.

Ethical statement: authors declare that they all agree with this publication and made significant contributions; that there is no conflict of interest of any kind; and that we followed all pertinent ethical and legal procedures and requirements. All financial sources are fully and clearly stated in the acknowledgements section. A signed document has been filed in the journal archives.

\section{ACKNOWLEDGMENTS}

This work was supported by the Secretaría General de Ciencia y Técnica, Universidad Nacional del Nordeste (UNNE; grant $\mathrm{N}^{\circ}$ PI17B007) and by the Agencia Nacional de Promoción Científica y Tecnológica (PICT 2016/1225). LACh, MEP and HHO are members of CONICET (National Scientific and Technical Research Council, Argentina).

\section{RESUMEN}

Caracterización, y actividad citotóxica en células gliales, de extractos enriquecidos con alcaloides de vainas de las plantas Prosopis flexuosa y Prosopis nigra (Fabaceae). Introducción: Las vainas de diversas especies de Prosopis muestran ser una potencial fuente de proteínas y energía para el ganado. Sin embargo, la ingestión prolongada de algunas de estas especies produce síntomas neurológicos en los rumiantes. Objetivo: En el presente estudio se determinó el contenido de alcaloides y la actividad neurotóxica in vitro de los extractos enriquecidos con alcaloides obtenidos en las vainas de $P$. flexuosa y $P$. nigra, con el fin de dilucidar el mecanismo de la intoxicación animal causada por estas especies. Métodos: Los principales alcaloides presentes en ambos extractos se analizaron mediante cromatografía líquida de alto rendimiento-espectrometría de masas de alta resolución (HPLC-HRMS). La actividad citotóxica de los extractos enriquecidos con alcaloides de Prosopis se determinó en cultivos primarios de células gliales mixtas y se evaluó mediante microscopía de contraste de fase y utilizando ensayos de actividad de rojo neutro y de deshidrogenasa láctica $(\mathrm{LDH})$. Resultados: Se identificaron la juliprosina y la juliprosopina en las vainas de $P$. flexuosa, mientras que se confirmó la ausencia de estos alcaloides piperidínicos en P. nigra. Ambos extractos $(5-30 \mu \mathrm{g} / \mathrm{mL})$ indujeron, de manera dependiente a la dosis, alteraciones morfológicas, como hinchazón, agrandamiento y desprendimiento de la superficie de cultivo. En consecuencia, la disminución de la viabilidad celular y la liberación de la LDH después de 48 horas de exposición, reveló que las vainas de $P$. flexuosa eran significativamente más citotóxicas que las de $P$. nigra. Conclusiones: El presente estudio muestra la presencia de los alcaloides juliprosina y juliprosopina en vainas de $P$. flexuosa y sugiere que el efecto citotóxico mostrado por ambos extractos se debe al contenido de alcaloides. Sin 
embargo, la presencia de estos alcaloides piperidínicos en $P$. flexuosa podría explicar la mayor citotoxicidad en las células gliales con respecto a $P$. nigra que no mostró que tuviera estos alcaloides.

Palabras clave: alcaloides piperidínicos; algarrobos; citotoxicidad; Prosopis species.

\section{REFERENCES}

Ahmad, V.U., Sultana, A., \& Qazi, S. (1989). Alkaloids from the leaves of Prosopis juliflora. Journal of Natural Products, 52, 497-501.

Assis, T.S., Medeiros, R.M., Araújo, J.A.S.D., Dantas, A.F., \& Riet-Correa, F. (2009). Intoxicações por plantas em ruminantes e equídeos no Sertão Paraibano. Pesquisa Veterinária Brasileira, 29(11), 919-924.

Biju, J., Sulaiman, C.T., Satheesh, G., \& Reddy, V. (2014). Spectrophotometric estimation of total alkaloids in selected Justicia species. International Journal of Pharmacy and Pharmaceutical Sciences, 6, 647-648.

Câmara, A.C.L., Costa, N.D.A., Riet-Correa, F., Afonso, J.A.B., Dantas, A.F., Mendonça, C.L.D., \& Souza, M.I.D. (2009). Intoxicação espontânea por vagens de Prosopis juliflora (Leg. Mimosoideae) en bovinos no Estado de Pernambuco. Pesquisa Veterinária Brasileira, 29(3), 233-240.

da Silva, V.D.A., da Silva, A.M.M., Silva, J.H.C., \& Costa, S.L. (2018). Neurotoxicity of Prosopis juliflora: from natural poisoning to mechanism of action of its piperidine alkaloids. Neurotoxicity Research, 34(4), 878-88.

dos Santos, E.T., Pereira, M.L.A., Da Silva, C.F.P., SouzaNeta, L.C., Geris, R., Martins, D., \& Figueiredo, M.P. (2013). Actividad antibacteriana del extracto enriquecido en alcaloides de las vainas de Prosopis juliflora y su influencia en la digestión ruminal in vitro. Revista Internacional de Ciencias Moleculares, 14(4), 8496-8516.

Hapon, M.B., Hapon, M.V., Persia, F.A., Pochettino, A., Lucero, G.S., \& Gamarra-Luques, C. (2014). Aqueous extract of Prosopis strombulifera (LAM) Benth induces cytotoxic effects against tumor cell lines without systemic alterations in $\mathrm{BALB} / \mathrm{c}$ mice. Journal Clinical Toxicology, 4(222), 2161-0495.

Henciya, S., Seturaman, P., James, A.R., Tsai, Y.H., Nikam, R., Wu, Y.C., \& Chang, F.R. (2017). Biopharmaceutical potentials of Prosopis spp. (Mimosaceae, Leguminosa). Journal of Food and Drug Analysis, 25(1), 187-196.

Hughes, J., Sousa, J., Barreto, R., Silva, A., Souza, C., Silva, V., \& El-Bachá, R.S. (2005). Cytotoxic effects of an extract containing alkaloids obtained from Prosopis juliflora Sw. DC (Algaroba) pods on glioblastoma cells. Revista Brasileira. Saúde Producao Animal, 6(1), 31-41.

Kumar, S., \& Mathur, M. (2014). Impact of invasion by Prosopis juliflora on plant communities in arid grazing lands. Tropical Ecology, 55(1), 33-46.

Lima, E., Riet-Correa, F., Amorin, S.L., \& Sucupira, G. (2004). Intoxicação por favas de Prosopis juliflora (algaroba) em caprinos no Nordeste do Brasil. Pesquisa Veterinaria Brasileira, 24(Supl.), 36-37.

Lomonte, B., Tarkowski, A., \& Hanson, L.A. (1994). Broad cytolytic specificity of myotoxin II, a lysine-49 phospholipase A2 of Bothrops asper snake venom. Toxicon, 32(11), 1359-1369.

Micheloud, J.F., Caro, L.A.C., Cholich, L.A., Martínez, O.G., \& Gimeno, E.J. (2019). Suspected poisoning in beef cattle from ingestion of Prosopis nigra pods in North-western Argentina. Toxicon, 157, 80-83.

Moro, G.A., Graziano, M.N., \& Coussio, J.D. (1975). Alkaloids of Prosopis nigra. Phytochemistry, 14, 827.

Ott-Longoni, R., Viswanathan, N., \& Hesse, M. (1980). Die konstitution des Alkaloides Juliprosopin aus Prosopis juliflora A. DC. Helvetica Chimica Acta, 63(222), 2119-2129.

Palacios, R.A., \& Brizuela, M.M. (2005). Flora Fanerogámica Argentina. Buenos Aires, Argentina: Proflora CONICET.

Pérez, M.J., Cuello, A.S., Zampini, I.C., Ordoñez, R.M., Alberto, M.R., Quispe, C., \& Isla, M.I. (2014). Polyphenolic compounds and anthocyanin content of Prosopis nigra and Prosopis alba pods flour and their antioxidant and anti-inflammatory capacities. Food Research International, 64, 762-771.

Repetto, G., del Peso, A., \& Zurita, J.L. (2008). Neutral red uptake assay for the estimation of cell viability/ cytotoxicity. Nature Protocols, 3, 1125-1131.

Ruiz-Nieto, J.E., Hernández-Ruiz, J., Hernández-Marín, J., Mendoza-Carrillo, J., Abraham-Juárez, M., Isiordia-Lachica, P.M., \& Mireles-Arriaga, A.I. (2020). Mesquite (Prosopis spp.) tree as a feed resource for animal growth. Agroforestry Systems, 1, 11.

Riet-Correa, F., de Andrade, F.R., Carvalho, F.K., Tabosa, I.M., Galiza, G.J., Bernardino, J.N. \& Medeiros, R.M. (2012). Utilização de vagens de Prosopis juliflora na alimentação de ovinos e caprinos. Pesquisa Veterinária Brasileira, 32(10), 987-989.

Schmeda-Hirschmann, G., Theoduloz, C., Jiménez-Aspee, F., \& Echeverría, J. (2020). Bioactive Constituents from South American Prosopis and their Use and Toxicity. Current Pharmaceutical Design, 26(5), 542-555. 
Silva, D.S. (1981). Substituição progressiva do farelo de trigo pela vagem da algaroba na alimentação de bovinos em engorda (Dissertação graduação). Paraíba, Brazil: Universidade Federal da Paraíba.

Silva, D.M.D., Riet-Correa, F., Medeiros, R.M., \& Oliveira, O.F.D. (2006). Plantas tóxicas para ruminantes e eqüídeos no Seridó Ocidental e Oriental do Rio Grande do Norte. Pesquisa Veterinária Brasileira, 26(4), 223-236.

Silva, A.M.M.D., Silva, A.R., Pinheiro, A.M., Freitas, S.R.V.B.D., Silva, V.D.A.D., Souza, C.D.S., \& Tardy, M. (2007). Alkaloids from Prosopis juliflora leaves induce glial activation, cytotoxicity and stimulate NO production. Toxicon, 49(5), 601-614.

Silva, V.D.A., Pitanga, B.P., Nascimento, R.P., Souza, C.S., Coelho, P.L.C., Menezes-Filho, N., ... Costa, S.L. (2013). Juliprosopine and Juliprosine from Prosopis juliflora leaves induce mitochondrial damage and cytoplasmic vacuolation on cocultured glial cells and neurons. Chemical Research in Toxicology, 26(12), 1810-1820.

Silva, V.D.A., Cuevas, C., Muñoz, P., Villa, M., AhumadaCastro, U., Huenchuguala, S., ... Costa, S.L. (2017). Autophagy protects against neural cell death induced by piperidine alkaloids present in Prosopis juliflora (Mesquite). Anais da Academia Brasileira de Ciências, 89(1), 247-261.
Soni, L.K., Dobhal, M.P., Arya, D., Bhagour, K., Parasher, P., \& Gupta, R.S. (2018). In vitro and in vivo antidiabetic activity of isolated fraction of Prosopis cineraria against streptozotocin-induced experimental diabetes: A mechanistic study. Biomedicine and Pharmacotherapy, 108, 1015-1021.

Tabosa, I.M., Quintans-Júnior, L.J., Pamplona, F.V., Almeida, R.N., Cunha, E.V.L., Silva, M.S., ... BarbosaFilho, J.M. (2000). Isolamento biomonitorado de alcalóides tóxicos de Prosopis juliflora (algaroba). Revista Brasileira de Farmacognosia, 9(10), 11-22.

Tabosa, I.M., Riet-Correa, F., Simões, S.V.D., Medeiros, R.M.T., \& Nobre, V.M.T. (2004). Intoxication by Prosopis juliflora pods (mesquite beans) in cattle and goats in Northeastern Brazil. In T. Acamovic, C.S. Stewart, \& T.W. Pannycott (Eds.), Toxic Plants and other Natural Toxicants (pp. 341-346). Wallingford, UK: CAB International Publishing.

Tabosa, I.M., Riet-Correa, F., Barros, S.S., Summers, B.A., Simões, S.V.D., Medeiros R.M.T., \& Nobre, V.M.T. (2006). Neurohistologic and ultrastructural lesions in cattle experimentally intoxicated with the plant Prosopis juliflora. Veterinary Pathology, 43, 695-701.

Tapia, A., Feresin, G.E., Bustos, D., Astudillo, L., Theoduloz, C., \& Schmeda-Hirschmann, G. (2000). Biologically active alkaloids and a free radical scavenger from Prosopis species. Journal of Ethnopharmacology, 71(1-2), 241-246. 